\title{
Açık Ekonomilerde Gelir Düzeyi, Kurumsal Faktörler ve Çalışma Tercihleri (Boş Zaman) iliş̧kisi: Küresel Bütünleşme Çalışma Yükümlülüğünü Azaltıyor mu?
}

\section{Relationship between Income Level, Institutional Factors and Working Preferences (Leisure Time) in Open Economies: Does Global Intergation Reduce Obligation of Work?}

\section{Dr. Öğr. Üyesi Aynur Yıldırım ${ }^{1}$ - Dr. Öğr. Üyesi Gonca Akgün Güngör²}

Başvuru Tarihi: 19.09.2018

Kabul Tarihi: 09.04.2019

\section{Öz}

Çalışmanın amacı, ekonomik ve kurumsal faktörlerin çalışma saatleri üzerindeki etkisinin analiz edilmesidir. Neo-klasik ekonomi modeli çerçevesinde birey zaman kullanımı konusunda karar vermek durumundadır. Buna göre birey; zamanının bir kısmını piyasada geçerli olan ücret düzeyinde çalışmak için, diğer bir kısmını da boş zaman olarak kullanmak amacıyla iki alternatif arasında paylaştıracaktır. Neo-klasik model, boş zamanı normal mal olarak kabul etmektedir. Normal mallar tüketicinin gelir düzeyi arttı̆̆ında talebi artan mallar olduğu için, bireyin gelir düzeyindeki artışa bağlı olarak, boş zaman talebinde de artış olması beklenmektedir. Diğer taraftan, toplumsal değerleri ifade eden kurumsal faktörler de birey davranışları üzerinde etkili olarak boş zaman tercihlerini etkilemektedirler. Çalışmada, bu sürecin nasıl işlediği, işe almaasgari ücret, işe alma-işten çıkarma ve toplu sözleşme gibi üç adet kurumsal yapı değiş̧kenine ilave olarak, kişi başına düşen GSYİH ve marjinal vergi oranı ve transfer ve sübvansiyonlar olmak üzere üç adet ekonomik değişkenin kullanılmasıyla incelenmeye çalışılmıştır.

Çalışmada öncelikle boş zaman kavramı açıklanmış, ardından Neo-klasik model çerçevesinde gelir değişmeleri ve boş zaman arasındaki etkileşime yer verilmiş, daha sonra da toplumun sahip olduğu kurumsal faktörler ve boş zaman arasındaki ilişkiler kurulmuştur. 2000-2015 dönemini kapsayan değişmelerin etkileri, Panel Veri Analizi yöntemi kullanılarak, 36 ülke için ekonometrik olarak test edilmiştir. Analiz sonuçlarına göre, "kişi başına düşen gelir", "toplu sözleşme olanaklarının yüksekliği”, "transfer ve sübvansiyonlar" ve "marjinal vergi oranı" değişkenleri ile "haftalık çalışma saatleri" arasında istatistiksel olarak anlamlı ve negatif bir ilişki bulunurken; "işe alma asgari ücret değişkenleri” ile "haftalık çalışma saatleri” arasında istatistiksel olarak anlamlı ve pozitif bir ilişki ortaya çıkmıştır. "İ̧se alma ve işten çıkarma" değişkeni ise anlamsız sonuç vermiştir.

\footnotetext{
${ }^{1}$ Muğla Sıtkı Koçman Üniversitesi Fethiye İşletme Fakültesi, aynury@mu.edu.tr, ORCID: 0000-0003-4292-6875

${ }^{2}$ Muğla Sıtkı Koçman Üniversitesi İİB, gonca@mu.edu.tr, ORCID: 0000-0003-4292-6875
} 
Anahtar Kelimeler: Boş Zaman, Ekonomik Gelişme, Kurumsal Faktörler, Çalışma Tercihleri Abstract

The aim of the study is to analyze the effects of economic and institutional factors on working hours. In the framework of the Neo-classical economy model, the individual has to decide on the use of time. Accordingly, the individual will divide his time into two alternatives: working at the current pay level or having free time. Neo-classical model considers leisure time as normal goods. Since normal goods are goods that increase in the demand when the consumer's income level increases, an increase in leisure time is also expected due to an increase in the individual's income level. On the other hand, the institutional factors expressing social values also affect leisure preferences by impacting on individual behavior. In an attempt to uncover how this process works, this study concentrates on three economics variables such as the per capita GDP, marginal tax rate, transfer and subsidies in addition to the three institutional structural factors such as hiring regulations and minimum wage, hiring and firing regulations and collective bargining.

In the study, firstly the concept of leisure time is explained, then the interaction between income changes and leisure time is given within the framework of the Neo-classical model and then the relations between institutional factors of the society and leisure time is established. The effects of the changes covering the period 2000-2015 were tested econometrically for 36 countries using the Panel Data Analysis method. According to the results of the analysis, there is a statistically significant and negative relationship between the "per capita GDP", "the high possibility of collective bargaining", "the transfers and subsidies", "the marginal tax rate" variables and "weekly working hours"; there is a statistically significant and positive relationship between "hiring regulations and minimum wage" variables and "weekly working hours". "The hiring and firing regulations", on the other hand, has yielded meaningless results.

Keywords: Leisure Time, Economic Development, Institutional Factors, Working Time Preferences

\section{Giriş}

Bireyler zamanlarının bir kısmını, yaşamlarını devam ettirebilmek amacıyla çalışmak için kullanırken, çalışmanın dışında kalan alternatif kullanım alanları, "boş zaman” olarak adlandırılmıştır. Bireyin çalışma süresini nasıl belirlediğini inceleyen Neo-klasik analiz, "çalışma” ve "boş zaman kullanımı" arasında zamanını paylaştırmak isteyen birey için "fayda maksimizasyonu"nu temel almaktadır. Buna göre, faydasını maksimize etmek isteyen birey, bazen emeğini arz etme kararı verirken, bazen de tam tersi hareket edebilmektedir. Bireyin çalışması sonucunda elde edeceği fayda, çalışmanın kendisine yükleyeceği maliyetin üzerinde ise emeğini arz etme yönünde karar vererek, fayda maksimizasyonunu gerçekleştirebilir. Ancak çalışmanın kendisine yükleyeceği maliyetin yüksek olacağına inanıyorsa, fayda maksimizasyonunu sağlamak için tercihini çalışmamaktan yana kullanabilir. Bu durumda Neo-klasik teoriye göre, bireyin çalışma kararı bir yandan ücret düzeyinden etkilenirken diğer 
taraftan bireyin çalışmaya bakış açısı da bu karar üzerinde etkili olmaktadır. Bireyin çalışmaya bakışı, ücret dışı gelirlerden, çalışma saatlerinden, iş güvenliğinin olup olmamasından ya da çalışma koşulları gibi faktörlerden etkilenmektedir (Shermana ve Shavit, 2013, s.12; Case, vd., 2012, s. 120-127; Williamson, 2002, s.105-110).

Neo-klasik ekonomi teorisine göre, ücret düzeyinin yükselmesi bireylerin gelir/boş zaman tercihlerini etkileyen, "ikame etkisi" ve "gelir etkisi" olarak adlandırılan birbirine zit iki etki meydana getirmektedir. Bu etkilerden “ikame etkisi”, boş zamanların fiyatının artması nedeniyle daha az boş vakit geçirmek ve işe daha fazla vakit ayırmak olarak ifade edilmektedir. İște harcanan zaman miktarı aynı iken toplam gelir arttığında, boş zaman taleplerinin de artması, "gelir etkisi" olarak adlandırılmaktadır (Gratton ve Taylor, 2004, s.86; Williamson, 2002, s.105-110; Case, vd., 2012, s. 120-122). Neo-klasik analize göre, fiyat değişikliği karşısında bireylerin gelir/boş zaman tercihlerinin ne yönde etkileneceği, birbirine zit bu iki etkiden hangisinin daha baskın olacağına göre şekillenmektedir.

Bireyin boş zaman tercihinde etkili olan değişkenlerden biri, gelir üzerinden alınan vergi oranlarıdır. Emek gelirleri üzerindeki yüksek oranlı vergiler, gelir düzeyinde azalmaya neden olduğu için, insanları çalışmak yerine boş zaman tercihine doğru yön değiştirmeye teşvik edecektir. Ekonomide boş zaman, piyasa değeri olan normal bir mal olarak kabul edilmektedir. Buna göre, devlet tarafından gerçekleştirilen transfer harcamaları da, bireylerin gelirlerinde bir artış yaratarak, normal mallara olan taleplerinin artmasına yol açacaktır. Böylece transfer harcamaları, bireylerin boş zaman tercihlerini arttırarak, daha az çalışmaları sonucunu ortaya çıkarabilmesi açısından boş zaman tercihini etkileyen bir diğer değişken olarak düşünülebilmektedir.

Neo-klasik modelin incelediği etkenlerin dışında, boş zaman tercihlerini etkileyecek farklı değişkenler de söz konusudur. Toplumun sahip olduğu değerler yani kurumsal faktörler; tüketim, tasarruf, eğitim ya da iş ahlâkı gibi en temel davranış şekillerinde bireyin davranışlarına yansıyarak, bireyin karar almasında ve davranışlarında onu yönlendirmektedir (Fellner, 2008, s. 112; Greif, 2006, s. 271; Kotler vd., 2005, s 115). Çalışmada, yukarıda söz edilen ekonomik değişkenlerin yanı sıra bireyin çalışma kararı ile kurumsal değişkenler arasında nasıl bir ilişki olduğu da ortaya konulmaya çalışılacaktır.

Kurumsal değişkenler arasında yer alan emek piyasası düzenlemelerinde esnek uygulamaların hayata geçirilmesinin boş zaman tercihlerini yönlendirdiği söylenebilir. Esnek istihdam sözleşmelerinin varlığı, işletmelerin rekabet gücünü arttırırken, çalışanlara çalışma sürelerini istedikleri gibi belirleyebilme imkânını tanımaktadır. Diğer taraftan firmalar çeşitli nedenlerle üretim sürecinde sözleşme ilişkilerini esnek bir şekilde kendi yapılarına uygun olarak kurmak isteyebilmektedirler. Firmaların sözleşme kurallarını kendilerinin belirlediği durumda da, çalışanlar bir takım hak talepleri karşısında daha savunmasızdırlar. Dolayısıyla esnek uygulamalara sahip emek piyasası, bireylerin boş zaman tercihi ya da çalışma istekleri üzerinde etkili olabilmektedir. 
Çalışmanın amacı, ekonomik ve kurumsal faktörlerin bireylerin çalışma saatleri (boş zaman) tercihleri üzerindeki etkilerini ortaya koyabilmektir. Bu amaçla ilk olarak boş zaman kavramı açıklanmış, gelir değişmeleri ve kurumsal faktörlerin çalışma saatleri üzerindeki etkisi teorik olarak incelenmiştir. Daha sonra ise 2000-2015 ylları arasındaki zaman dilimini kapsayan değişmelerin etkileri, 36 ülke için, Panel Veri Analizi yöntemi ile ekonometrik olarak test edilmiştir.

\section{Boş Zaman ve Boş Zaman Tercihi Kavramı}

Neo-klasik ekonomi çerçevesinde çalışmaktan arta kalan zaman dilimi olarak tanımlanan boş zaman, sosyolojik açıdan; iş'in zorlayıcı dünyasından gevşeme, ferahlama ve de kendini salıverme durumuna bir kaçı̧ olarak ifade edilmektedir (Hibbins, 1996, s.23). Çalışmaktan arta kalan, zorunluluktan uzak, kurumsal zorunluluklardan gelen yorgunluğun neden olduğu fiziki ve psikolojik güç kaybının tekrar kazanılmasını sağlayacak zaman dilimini ifade etmektedir (Smelder ve Swedberg, 2001; Aytaç, 2002, s.232). Buna göre boş zaman, bireyin verimliliğini arttıran, refah düzeyinin yükselmesine katkı sağlayan zaman dilimidir.

Bireyin daha fazla boş zaman talep etmesi demek, çalışma ve çalısmama faaliyetleri arasında zamanın yeniden dağıtılması anlamına gelmektedir. Tüketmeye karar verilen her bir boş zaman saati için bir saatlik ücretten vazgeçilmiş olunmaktadır. Buna bağlı olarak boş zamanın fiyatı da ücret düzeyi ile açıklanmaktadır. Gelir düzeyi, kurumsal faktörler, zevk ve tercihler doğrultusunda her birey boş zaman için farklı bir değer biçmektedir (Case, vd., 2012, s. 124).

\section{Gelir Değişmeleri ve Kurumsal Faktörler ile Boş Zaman Arasındaki ilişki}

1980 'li yıllardan itibaren tüm dünyada ağıllı̆ını hissettiren küreselleşme süreci, ekonomilerin dışa açılmasıyla birlikte rekabet baskısının ön plana çıkmasına yol açmışır. İktisadi gelişme, gelir değişmeleri ve teknolojik gelişme ile birlikte kültür, alışkanlıklar, yaşam tarzı, hayat algısı gibi toplumun alt yapı kurumlarını dönüştürerek kurumsal yapıyı değiş̧tirirken, boş zaman algısının da değişmesine yol açmıştır. Küreselleşme eğilimiyle birlikte yaşanan bu değişimin emek piyasaları üzerindeki etkisi ise, çalışma sürelerinin esnekleştirilmesinin ilke olarak benimsenmesi ve çalışma saatlerindeki önemli değişimler şeklinde olmuştur. Küreselleşme ile birlikte çalı̧̧ma-boş zaman arasındaki ilişkinin yönü, boş zamana doğru kayma göstermiştir.

Çalışma alanındaki dönüşümler 18. yüzylla birlikte önemli bir ivme kazanmıştır. 1700'ler boyunca boş vakti "başıboşluk" ve "israf" zamanı olarak gören püritenizm, aylaklığı, hedonizmi, harcamayı, başıboşluğu günah olarak nitelendirmiştir. Çalışmaya, tasarrufa, çileciliğe, hazzı ertelemeye kutsiyet atfederek sermaye oluşumunu teşvik etmiştir. Endüstri devrimi, çalışma saatlerinde önemli bir artış yaşanmasına yol açmıştır. Üretimi artırmak amaç olduğundan, işçilerin sömürülmesi, güç ve elverişsiz koşullara maruz bırakılmaları bu dönemde yaygınlık kazanmıştır. Ancak, işçinin artan sömürüsü, daha az çalışma saati ve daha fazla ücret talep eden bir iş̧̧i hareketine yol açmış ve zamanla uzun çalışma süreleri yavaş yavaş düşmeye başlamıştır (Juniu, 2000, s.70). 
Diğer taraftan endüstriyel üretimde, makinaların merkezi rol üstlenmeleri, çalışma sürelerini aşağı çekerken boş zamanın artmasını sağlamıştır. Üretimde makinaların etkin kullanılması aktif insan gücüne olan gereksinimi azaltarak bireyin daha çok sevk ve idareyi sağlayıcı fonksiyonunu ön plana çıkarmıştır. Bu durum çalışma sürelerinin kısaltılmasını da beraberinde getirmiştir (Aytaç, 2005, s.6). I. Dünya Savaşı'na kadar çalışan başına çalışma saatlerinin Fransa ve Almanya dâhil çoğu Avrupa ülkesine göre ABD’de aslında daha düşük olduğu görülmektedir. Sonra, Fransa ve Almanya dâhil Avrupa ve ABD’de çalışan başına çalışma saatleri aynı iken 1960'ların sonuna kadar çalışma saatleri Avrupa'da ABD'den biraz daha fazla düşmeye başlamıştır (Huberman, 2004).

Konuyla ilgili iktisadi literatür, gelir değişimlerinin boş zaman tercihini etkilediğini ortaya koymaktadır. Gelir ve boş zaman arasındaki denge, bireyin ne kadarlık gelir karşılığında bir saatlik boş zamanını feda edeceği ile ifade edilmektedir (Singh, 2016). Boş vakit geçirmek istenilen her zaman potansiyel kazançların kaybedilmesi anlamına gelmektedir, böylece geçmiş kazançlar, boş zamanın fiyatı ya da firsat maliyeti olarak belirtilmektedir (Gratton ve Taylor, 2004, s.86).

Emek gelirlerinin vergilendirilmesindeki farklılıklar, bireylerin çalışma tercihleri üzerinde etkili olmaktadır (Prescott, 2004, s.6). Gelir üzerindeki yüksek oranlı vergiler, insanları çalışmak yerine boş zaman tercihine doğru yön değiştirmeye teşvik etmektedir. İsveç ve ABD için yapılan incelemede, ABD'de vergi oranlarının İsveç'e göre daha düşük olduğu belirtilmiş ve vergi oranlarının düşük olmasının ABD'de üretimi ve çalışmayı çekici duruma getirdiği ifade edilmiştir. İsveç de ise, bireyin geliri üzerinden alınan vergilerin yüksek olmasının, piyasada çalışmak yerine boş zaman tercihini arttırdığı sonucuna ulaşılmıştır (Olovsson, 2009).

Vergi oranları (sabit olmadığı varsayıldığında) emek arzını etkilemektedir. Eğer emek geliri üzerindeki vergi oranlarının gelecekte daha yüksek olacağı beklenirse, insanlar bu anda daha düşük tüketim/gelir (C/Y) bileşimini seçer ve işgücü arzı yüksek olur. Gelir üzerinden alınan vergi oranlarının arttırılıp azaltılması bir anlamda emek gelirlerinin artması veya azalması anlamına gelebilmektedir. Örneğin ücretler üzerinden alınan vergi oranları düşürülür ise, bu durum gelir düzeyinde bir artış sonucunu doğuracaktır. Gelir arttıkça, şayet gelir etkisi kuvvetli ise çalışma süreleri artacaktır, ikame etkisi kuvvetli ise çalışma süreleri düşecektir (Mocan ve Pogorelova, 2015, s.23; Prescott, 2004; Meghir ve Phillips, 2008, s.7).

Transfer harcamaları, devlet borçlarının faizleri, gazilere ve malullere ödenen maaşlar, işsizlik yardımı, yaşlılara, dul ve yetimlere yapılan ödemeler, öğrencilere verilen burslar şeklinde örneklendirilebilir. Devlet tarafından genellikle tarım sektöründe faaliyet gösteren üreticilere verilen destekler olarak ifade edilen sübvansiyonlar da transfer harcamalarının bir parçası olarak görülmektedir. Transfer harcamaları, yoksulluğu azaltmak ve ek bir satın alma gücü sağlamak gibi etkileri nedeniyle, büyüme için elverişli bir ortam sağlar (Mckenzie vd., 1997, s.7).

Transfer harcamaları, bireylerin gelirlerinde bir artış yaratarak, normal mallara olan taleplerinin artmasına yol açar. Ekonomide boş zaman, piyasa değeri olan, pazarda satış nesnesi 
olan, bireyi tatmin eden zevklerin getirdiği normal bir mal olarak kabul edilmektedir. Buna bağlı olarak, transfer harcamaları, bireylerin daha az çalışmaları sonucunu ortaya çıkarabilmektedir (Conway, 1997, s.50). Diğer taraftan transfer harcamaları arasında gösterilen işsizlik sigortası ödeneği bireylerin emek arzı üzerinde etkili olabilmektedir. Herhangi bir işte çalışıkları takdirde işsizlik ödeneğinin kesileceğini düşünen bireyler çalışma konusunda isteksiz davranarak boş zaman tercihlerini arttırabilmektedirler.

Esnek emek piyasası düzenlemeleri, genellikle ekonomik kriz dönemlerinde söz konusu olmakla birlikte, gelişmiş ülkelerde teknolojinin hızla gelişmesi ve sanayi sektöründen hizmet(ler) sektörüne geçilmesi gibi nedenlerle yapılmaktadır. Yaşanan teknolojik gelişmeler ve ekonomik yapıdaki değişim sonucunda ortaya çıkan işsizlik düzeyindeki artışlar karşısında kısa süreli istihdam sözleşmeleri bir çözüm olarak ortaya konulabilmektedir. Böylece, istihdam ve üretimin devamlllğ̆ının sağlanması ekonomi üzerinde olumlu katkılarda bulunabilmektedir. Ayrıca gelişmiş ülkelerde çalışanlar, eğitim görme ve diğer aktivitelere katılma gibi nedenlerle de kısa süreli istihdam sözleşmelerini ve esnek uygulamaları tercih edebilmektedirler. Esnek istihdam sözleşmelerinin varlığı, işletmelerin rekabet gücünü arttırırken, çalışanlara ise çalışma sürelerini istedikleri gibi belirleyebilme imkânını tanımaktadır. Bu durum kadınların işgücüne katılım oranlarının artmasına da olanak vermektedir.

Diğer taraftan firmaların üretim sürecinde yeni yöntemleri serbestçe deneyebilmeleri, teknolojik ilerleme ve buluşlar konusunda daha etkin olmalarını sağlamaktadır. Bu nedenle firmalar, yeni üretim yöntemlerini denemek, hızlı teknolojik gelişmelere çalışanların aynı hızla uymalarını sağlamak, ücret sisteminde esnek uygulamalara kavuşabilmek, yönetimde karar verme serbestisini kullanabilmek gibi nedenlerle, sözleşme ilişkilerini esnek bir şekilde kendi yapılarına uygun olarak kurmak isteyebilmektedirler. Ancak, firmaların sözleşme kurallarını kendilerinin belirlediği durumda da, çalışanların eğitim, işs sağlığı, sosyal güvenlik, ücret gibi alanlardaki hak talepleri karşısında daha savunmasızdırlar. Bu açıllamalar bağlamında, firmaların sözleşmeleri kendi çıkarlarına uygun şekilde oluşturmak istemeleri durumunda da bireylerin çalışma isteklerinde azalma görülebilecektir.

\section{Boş Zaman Tercihi Literatür Taraması}

Dünya Değerler Araştırması (WSS) anket verileri üzerinden yapılan çalışmaya göre, gelir eşitsizliği ve boş zaman miktarı arasında negatif ilişki vardır. Boş zaman miktarı ve kültürel aktivitelere katılım oranına bakıldığında, gelir dağılımının nispeten daha eşit düzeyde olduğu ülkelerde boş zaman süresinin ve kültürel aktivitelere katılım oranlarının daha yüksek olduğu görülmektedir. (Veal, 2016). Nitekim, Monostori (2009) tarafindan WSS anket verileri kullanılarak yapılan çalışmada, Avrupa Birliği üyesi ülkelerde boş zamanın çalışmaktan daha değerli olduğu ortaya konmuştur.

Boş zaman tercihi üzerine Kozaryn (2011) tarafından gerçekleştirilen çalışmada, WSS, Eurobarometer ve Genel Sosyal Anketlerine ait veriler kullanılmış ve Amerikalıların Avrupalılardan daha fazla çalıştı̆̆ı sonucuna ulaşılmıştır. Aynı çalışma, çalışma saatleri arttıkça Amerikalıların Avrupalılardan daha fazla mutlu olduğunu ortaya koymuştur. Amerikalıların 
Avrupalılardan daha fazla çalıştığı Michelacci ve Pijioan-Mas (2007) tarafından da desteklenmiştir. Benzer şekilde, Olovsson (2009), ABD’deki çalışma saatlerinin Avrupa ülkelerinden yaklaşık \%10 daha fazla olduğunu; Prescott (2004) ise, Amerikalıların Almanlar, Fransızlar ve İtalyanlar'dan \%50 daha fazla çalışıyor olduğunu göstermiştir.

Kişi başına haftalık çalışma saatlerinin ABD'de Avrupa ülkelerine göre daha fazla olduğu Alesina vd. (2006) tarafından da ortaya konmuştur. Konu ile ilgili yapılan birçok çalışmada Avrupa ülkelerinde çalışma saatlerinin daha kısa olduğu belirtilirken, İngiltere'de uzun çalışma saatleri istemeyen işçilerin birçoğunun çalışma saatlerinin uygulamada uzun olduğu belirtilmiştir (Wheatley vd., 2011).

Conway (1997)'e göre, kamu transfer harcamalarının artması, emek arzının düşmesiyle sonuçlanacaktır. Rodríguez (2016) ise, ABD ekonomisi için kamu harcamalarının dinamik etkilerini incelediği çalışmasında, transfer harcamalarının emek piyasasını olumsuz etkilediğini belirtmiştir.

Yüksek vergi oranları işgücü arzı ve istihdam oranları üzerinde olumsuz etkilere yol açmaktadır (Kleven ve Kreiner, 2005; Rogerson, 2007; Nickell, 2004, Conway, 1997). Ayrıca Prescott (2004), Avrupa'da vergi oranlarının azaltılmasının çalışma saatleri ve refah üzerinde pozitif katkılarda bulunacağını belirtmiştir. Meghir ve Phillips (2008) ise vergi oranlarında yapılacak indirimlerin işgücü arzı üzerinde büyük artışlar yaratacağını vurgulamışlardır. Mocan ve Pogorelova (2015), WVS ve Avrupa Değerler Çalışması (EVS) verilerini kullanarak, 26 Avrupa ülkesi için 2000-2012 dönemini kapsayacak şekilde yaptıkları incelemede, cinsiyete göre vergi oranlarının ve boş zaman kültürünün işgücüne katılma oranı üzerindeki etkilerini incelemişlerdir. Çalışmanın sonucu, kadınlar için hem vergi hem de boş zaman kültürünün işgücüne katılma oranını ve çalışma saatlerini etkilediğini ortaya koymuştur. Aynı çalışma, erkekler için ise, vergilerin işgücü arzını yoğun ve geniş bir marjda etkilediğini, boş zaman kültürünün ise işgücü arzı üzerinde etkisinin olmadığını göstermiştir. Dokko (2007), vergi oranlarının işgücü arzı üzerindeki etkilerini incelemek amacıyla yaptığı çalışmada, daha yüksek vergi oranlarıyla karşı karşıya kalan annelerin yılda ortalama 40 saat daha az çalıştıkları, babalar için ise fark edilir bir etkinin olmadığı sonucuna ulaşmıştır.

\section{Veri ve Yöntem}

\section{Veri Seti, Yöntem ve Analiz Sonuçları}

Ekonomik ve kurumsal faktörlerin toplumların çalışma saatleri üzerindeki etkisini açıklamayı amaçlayan çalışmada, sözü edilen bu etki, 36 ülke üzerinden incelenmeye çalışılmıştır. Söz konusu ilişki, işe alma-asgari ücret, işe alma-işten çıkarma ve toplu sözleşme gibi üç adet kurumsal yapı değişkenine ilave olarak, kişi başına düşen GSYİH ve marjinal vergi oranı ve transfer ve sübvansiyonlar olmak üzere üç adet ekonomik değişkeninin kullanılmasıyla, 20002015 yılları arasındaki zaman dilimi için araştırılmıştır. Ülkelerin kurumsal yapısını ortaya koyacak veriler yaygın olarak, uluslararası kuruluşlar tarafından açıklanan endekslerden oluşmaktadır. Analizde kullanılacak olan kurumsal yapı göstergeleri için Economic Freedom of the World endeks verilerinden yararlanılırken; kişi başına düşen GSYİH ve haftalık çalışma 
saatleriyle ilgili verilerin derlenmesinde, WB (The World Bank), OECD (The Organisation for Economic Co-operation and Development) istatistikleri ve TÜİK (Türkiye İstatistik Kurumu) verileri kullanılmıştır. Tablo 1'de çalışmada kullanılan değişkenler gösterilmiştir.

Tablo 1. Analizde Kullanılan Değişkenler

\begin{tabular}{|c|c|c|}
\hline Değişkenler & Açıklama & Veri Kaynağı \\
\hline $\begin{array}{l}\text { Bağımlı Değişken } \\
\text { Haftalık çalışma saatleri }\end{array}$ & Kişi başına haftalık çalışma saati & OECD \\
\hline $\begin{array}{l}\text { Bağımsız Değişkenler } \\
\text { * Ekonomik Değişken } \\
\text { Kişi başına düşen GSYïH } \\
\text { Transfer ve sübvansiyonlar } \\
\text { Marjinal vergi oranı }\end{array}$ & $\begin{array}{l}\text { SGP Sabit Fiyatlarla \$ } \\
\text { Endeks değerleri } \\
\text { Endeks değerleri }\end{array}$ & $\begin{array}{l}\text { Dünya Bankası (WB) } \\
\text { Economic Freedom of the World } \\
\text { Economic Freedom of the World }\end{array}$ \\
\hline $\begin{array}{l}\text { * Kurumsal Değişkenler } \\
\text { İşe alma-asgari ücret } \\
\text { İşe alma- işten çıkarma } \\
\text { Toplu sözleşme }\end{array}$ & $\begin{array}{l}\text { Endeks değerleri } \\
\text { Endeks değerleri } \\
\text { Endeks değerleri }\end{array}$ & $\begin{array}{l}\text { Economic Freedom of the World } \\
\text { Economic Freedom of the World } \\
\text { Economic Freedom of the World }\end{array}$ \\
\hline
\end{tabular}

Panel Veri Analiz yönteminin kullanılmasıyla gerçekleştirilen analizde bağımlı değişken haftalık çalışma saatleri iken; bağımsız değişkenler kişi başına düşen GSYİH, transfer ve sübvansiyonlar, marjinal vergi oranı, işe alma-asgari ücret, işe alma-işten çıkarma ve toplu sözleşmeler'dir.

Tablo 1'de verilen kurumsal yapı değişkenlerinin niteliği ve hesaplama biçimlerine bakıldığında, ilk olarak Transfer ve Sübvansiyonlar değişkenine ait endeks, ülkedeki transfer ve sübvansiyon uygulamalarının GSYİH'ya oranını vermektedir. Endeks, 0-10 arasında değerler almaktadır. Endeks değerlerinin artması, ülkenin yıl içinde gerçekleştirdiği transfer ve sübvansiyon alanının genişlediğini (hükümet müdahalesinin arttığını); azalması ise transfer ve sübvansiyon alanındaki daralmayı (hükümet müdahalesinin azaldığını) ifade etmektedir (EFW, 2012, s.271).

Marjinal Vergi Oranı değişkenine ait endeks, vergi mükelleflerinin gelirlerindeki bir artışın ödenecek vergi miktarında yol açtığı değişim, olarak hesaplanmıştır. Endeksin hesaplanmasında, gelir eşiklerine ait veriler ülkelerin ulusal para birimlerinden Amerikan Doları'na dönüştürülmüştür (1982/1984 ABD Tüketici Fiyat Endeksi ve yıllık döviz kurları kullanılarak). Endeks, 0-10 arasında değerler almaktadır. Endeks değerlerinin artması, marjinal vergi oranının yüksek olduğunu; endeks değerlerinin azalması ise marjinal vergi oranının düşük olduğunu göstermektedir (EFW, 2012, s.272). 
İşe Alma ve Asgari Ücret Düzenlemeleri endeksi, Dünya Bankası (WB Doing-Business) verilerine dayanmaktadır (EFW, 2012, s.280-281). Endeksin hesaplanmasında, kalıcı görevler için belirli süreli sözleşmelerin yasaklanmış olup olmadığı, sabit dönemli sözleşmelerin maksimum kümülatif süresi ve stajyer ya da ilk kez çalışanlar için asgari ücret oranları göz önünde bulundurulmuştur. Buna göre, endeks değerlerinin yüksek olması, istihdam sözleşmelerinin süresinin uzun olduğunu ifade ederken; endeks değerlerinin düşük olması ise, esnek istihdam sözleşmelerinin olduğu emek piyasasının varlığına işaret etmektedir.

Isşe Alma ve Isşten Çıkarma Düzenlemeleri endeksi, Dünya Ekonomik Forumu, Küresel Rekabet Raporuna dayanmaktadır (EFW, 2012, s.281). Bu endeks, Küresel Rekabet Gücü Raporunda sorulan, "İşçilerin işe alınması ve işten çıkarılması düzenlemelerle engellenmekte midir yoksa işverenler tarafından esnek uygulamalar bulunmakta mıdır?” sorusuna verilen cevaplardan yararlanılarak hesaplanmıştır. Endeks, 1-7 arasında değerler almaktadır. Endeks değerlerinin düşmesi, işçi çlkarmanın zor olduğunu, istihdam güvencesinin olduğunu gösterirken; endeks değerlerinin yüksek olması, işçi çıkarmanın kolay olduğu esnek uygulamaların bulunduğunu göstermektedir.

Toplu Sözleşme endeksi, Dünya Ekonomik Forumu, Küresel Rekabet Raporuna dayanmaktadır (EFW, 2012, s.281). Bu endeks, Küresel Rekabet Gücü Raporunda sorulan, "Ülkenizde ücretler, merkezi pazarlık süreci ile mi ayarlanmaktadır?” sorusuna verilen cevaplardan yararlanılarak hesaplanmıştır. Endeks, 1-7 arasında değerler almaktadır. Endeks değerlerinin düşmesi, ücretlerin merkezileşmiş pazarlık süreci ile ayarlandığını (bağımsızlığın olmadığını) gösterirken; endeks değerlerinin yükselmesi, şirketlerin toplu sözleşmeleri kendilerinin belirleyebildiklerini (bağımsız olduklarını) göstermektedir. Tablo 2‘de, analizde kullanılan kurumsal yapı değişkenlerinin nitelikleri özetlenmiştir.

Tablo 2. Kurumsal Yapı Değişkenlerinin Niteliklerinin Tanımlanması

\begin{tabular}{|c|c|c|c|c|}
\hline DEĞiŞKENLER & $\begin{array}{l}\text { ENDEKS } \\
\text { DEĞERI }\end{array}$ & AÇIKLAMA & $\begin{array}{l}\text { EN } \\
\text { DEKS } \\
\text { DEĞERI }\end{array}$ & AÇIKLAMA \\
\hline $\begin{array}{l}\text { Transfer ve } \\
\text { Sübvansiyonlar }\end{array}$ & Artması & $\begin{array}{l}\text { Transfer ve sübvansiyon alanındaki artış } \\
\text { (hükümet müdahalesi artmıştır). }\end{array}$ & Azalması & $\begin{array}{l}\text { Transfer ve sübvansiyon } \\
\text { alanındaki azalış (hükümet } \\
\text { müdahalesi azalmıştır). }\end{array}$ \\
\hline $\begin{array}{l}\text { Marjinal Vergi } \\
\text { Oranı }\end{array}$ & Artması & Marjinal vergi oranı yüksektir. & Azalması & Marjinal vergi oranı düşüktür. \\
\hline $\begin{array}{l}\text { İşe Alma- Asgari } \\
\text { Ücret } \\
\text { Düzenlemeleri }\end{array}$ & Artması & $\begin{array}{l}\text { Esnek istihdam sözleşmelerinin olduğu } \\
\text { emek piyasasının varlığına işaret } \\
\text { etmektedir. }\end{array}$ & Azalması & $\begin{array}{l}\text { İstihdam sözleşmelerinin } \\
\text { süresinin uzun olduğunu ifade } \\
\text { etmektedir. }\end{array}$ \\
\hline $\begin{array}{l}\text { İşe Alma-i̇şten } \\
\text { Çıkarma } \\
\text { Düzenlemeleri }\end{array}$ & Artması & $\begin{array}{l}\text { İşçi çıkarmanın kolay olduğu esnek } \\
\text { uygulamaların varlığını göstermektedir. }\end{array}$ & Azalması & $\begin{array}{l}\text { İşçi çıkarmanın zor olduğunu ve } \\
\text { istihdam güvencesinin varlığını } \\
\text { göstermektedir. }\end{array}$ \\
\hline Toplu Sözleşme & Artması & $\begin{array}{l}\text { Şirketlerin toplu sözleşmeleri } \\
\text { kendilerinin belirleyebildiklerini } \\
\text { (bağımsız olduklarını) göstermektedir. }\end{array}$ & Azalması & $\begin{array}{l}\text { Ücretlerin merkezileşmiş pazarlık } \\
\text { süreci ile ayarlandığını } \\
\text { (bağımsızlığın olmadığını) } \\
\text { göstermektedir. }\end{array}$ \\
\hline
\end{tabular}


Çalışmanın uygulama kısmında ekonomik ve kurumsal faktörlerin toplumların çalışma saatleri üzerindeki etkilerini ölçmek için kullanılan ülkelere Tablo 3'de yer verilmiştir.

Tablo 3. Analizde Kullanılan Ülkeler

\begin{tabular}{|c|c|c|c|c|c|c|c|c|c|c|c|}
\hline $\begin{array}{l}\text { Sira } \\
\text { No }\end{array}$ & Ülkeler & $\begin{array}{l}\text { Sira } \\
\text { No }\end{array}$ & Úlkeler & $\begin{array}{l}\text { Sira } \\
\text { No }\end{array}$ & Ülkeler & $\begin{array}{l}\text { Sira } \\
\text { No }\end{array}$ & Ülkeler & $\begin{array}{l}\text { Sira } \\
\text { No }\end{array}$ & Ülkeler & $\begin{array}{l}\text { Sira } \\
\text { No }\end{array}$ & Ülkele \\
\hline 1 & Avustralya & 7 & Slovenya & 13 & Yunanistan & 19 & Japonya & 25 & İspanya & 31 & Şili \\
\hline 2 & Avusturya & 8 & Danimarka & 14 & Macaristan & 20 & G.Kore & 26 & İtalya & 32 & Norves \\
\hline 3 & Belçika & 9 & Estonya & 15 & İzlanda & 21 & Letonya & 27 & Polonya & 33 & Rusya \\
\hline 4 & Kanada & 10 & Finlandiya & 16 & İrlanda & 22 & Litvanya & 28 & Portekiz & 34 & İsveç \\
\hline 5 & Türkiye & 11 & Fransa & 17 & Almanya & 23 & Meksika & 29 & Amerika & 35 & İsrail \\
\hline 6 & $\begin{array}{l}\text { Yeni } \\
\text { Zelanda }\end{array}$ & 12 & $\begin{array}{l}\text { Birleşik } \\
\text { Krallık }\end{array}$ & 18 & Çek Cumh. & 24 & Hollanda & 30 & Slovakya & 36 & $\begin{array}{l}\text { Kosta } \\
\text { Rika }\end{array}$ \\
\hline
\end{tabular}

Panel Veri Analizi yönteminin kullanılmasıyla yapılan ölçümler için Stata 11 paket programından yararlanılmıştır. Panel veri analizinde birey etkilerini görmek için kullanılan sabit etki (fixed effect) ve rassal etki (random effect) modellerinden hangisinin seçileceği Hausman testi çerçevesinde belirlenen bir sorundur (Tatoğlu, 2013, s.179). Hausman testi sonucuna göre $(0.0000<0.05)$, sabit etkiler tahmincisinin tutarlı olduğu ortaya çıkmıştır.

Modelde yatay kesit bağımlılı̆̆ının olup olmadığı, Friedman Testi ile sınanmıştır. Test sonuçlarına göre (testin olasılık değeri $(0.0000)<0.05)$, birimler arası korelasyonun varlığ ortaya çıkmış ve bu nedenle, birimler arası korelasyonu dikkate alan ikinci kuşak birim kök testlerinden Pesaran Panel Birim Kök Testi kullanılmıştır. Pesaran'ın CADF Testi sonuçları Tablo 4'de verilmektedir.

Tablo 4. Pesaran'ın CADF Birim Kök Testi Sonuçları

\begin{tabular}{|c|c|c|}
\hline Değişkenler & t-istatistiği & Olasilık \\
\hline $\begin{array}{ll}\text { Haftalık çalışma saatleri } \\
\text { (0) }\end{array}$ & -2.000 & $0.023 *$ \\
\hline $\begin{array}{ll}\text { (0) } & \text { Kişi başına düşen gelir } \\
\end{array}$ & -1.706 & 0.044* \\
\hline $\begin{array}{cc}\text { Transfer } & \text { ve } \\
\text { sübvansiyonlar }(0) & \\
\end{array}$ & -1.712 & $0.043 *$ \\
\hline Marjinal vergi oranı (0) & -1.661 & $0.048^{*}$ \\
\hline $\begin{array}{ll}\text { (0) } & \text { Isse alma ve asgari ücret } \\
\end{array}$ & -6.826 & $0.000 *$ \\
\hline (0) İşe alma ve işten çıkarma & -1.850 & $0.032 *$ \\
\hline $\begin{array}{l}\text { Toplu sözleşme (0) } \\
\text { Toplu sözleşme (1) }\end{array}$ & $\begin{array}{r}0.529 \\
-6.398 \\
\end{array}$ & $\begin{array}{l}0.702 * \\
0.000 *\end{array}$ \\
\hline
\end{tabular}

* \%0,05 düzeyinde istatistiksel olarak anlamlıdır. 
Pesaran'ın birim kök testi doğrultusunda, bağımlı değişken haftalık çalışma saatleri ile bağımsız değişkenlerden kişi başına düşen gelir, transfer ve sübvansiyonlar, marjinal vergi oranı, işe alma ve asgari ücret, işe alma ve işten çıkarma değişkenleri düzeyden durağandır. Toplu sözleşme değişkeni ise, birinci dereceden durağan olduğundan, değişkenin birinci dereceden farkları alınarak modele eklenmiştir. Durağan verilerle model yeniden kurularak analiz tekrarlanmıştır. Modele tekrar uygulanan Hausman testinin sonuçları, $(0.0000>0.05)$ sabit etkiler tahmincisinin tutarlı olduğunu ortaya koymuştur.

Ekonometrik analizlerde, otokorelasyon problemine yatay kesit verilerinde rastlansa da uygulamada daha çok zaman serilerinde karşılaşılan bir durumdur. Otokorelasyon, çoklu regresyon analizinde hata teriminin birbirini izleyen değerleri arasında ilişki bulunması halidir. $\mathrm{Bu}$ durum, genel doğrusal regresyon modelinin önemli bir varsayımından sapmadır. Genel doğrusal regresyon modeli varsayımının gereği olarak, hata terimleri arasında bir ilişki yoktur. Çalışmamızda, sabit etkiler üzerinden kurulan modelimizde otokorelasyonun var olup olmadığı Baltagi-Wu'nun LBI testleri ile sınanmıştır. Literatürde kritik değerler verilmemesine rağmen, değer 2'den küçükse otokorelasyonun önemli olduğu yorumu yapılmaktadır (Tatoğlu, 2013, s.214). Buna göre Baltagi-Wu LBI test sonucu (Durbin-Wats Baltagi-Wu LBI = 0.38949273, Baltagi-Wu LBI = 0.7107489) şeklinde olup, her iki test için de değerler 2'den oldukça küçük olduğu için otokorelasyonun olduğu yorumu yapılabilmektedir.

Sabit etkiler modelinde birimlere göre heteroskedasitenin var olup olmadığı Değiştirilmiş Wald testi kullanılarak sınanmıştır. Yapılan test sonucunda "birimlerin varyansları eşittir" şeklinde kurulan $\mathrm{H}_{0}$ hipotezi reddedilmektedir $(0.0000<0.05)$. Bu durumda kurulan modellerde heteroskedasite olduğu anlaşılmaktadır.

Sabit etkiler üzerinden kurulan model için yapılan testlerin sonucuna göre birimler arası korelasyon, heteroskedasite ve otokorelasyon olması nedeniyle, bu problemleri ortadan kaldıran düzeltme modeli Driscoll ve Kraay Tahmincisi (Havuzlanmış En Küçük Kareler Yöntemi) kullanılmıştır. Buna göre, elde edilen tahmin sonuçlarına Tablo 5'de yer verilmiştir.

Tablo 5. Ekonomik ve Kurumsal Faktörlerin Toplumların Çalışma Saatleri Üzerindeki Etkisi

\begin{tabular}{|c|c|c|}
\hline \multicolumn{3}{|c|}{ Bağımlı Değişken: Haftalık Çalışma Saatleri } \\
\hline Bağımsız Değişkenler & $\begin{array}{c}\text { Katsayı } \\
\text { (Standart Hata) }\end{array}$ & $\begin{array}{c}t \\
(P>|t|)\end{array}$ \\
\hline Kişi Başına Düşen Gelir & $\begin{array}{c}-0.1768 \\
(0.0170)\end{array}$ & $\begin{array}{c}-10.36 \\
(0.000)^{*}\end{array}$ \\
\hline Transfer ve Sübvansiyonlar & $\begin{array}{l}-0.1164 \\
(0.0050) \\
\end{array}$ & $\begin{array}{c}23.12 \\
(0.000)^{*}\end{array}$ \\
\hline Marjinal Vergi Oranı & $\begin{array}{l}-0.0335 \\
(0.0084)\end{array}$ & $\begin{array}{c}3.98 \\
(0.000)^{*}\end{array}$ \\
\hline İşe Alma-Asgari Ücret & $\begin{array}{c}0.0155 \\
(0.0049)\end{array}$ & $\begin{array}{c}3.16 \\
(0.003)^{*}\end{array}$ \\
\hline İşe Alma-İşten Çıkarma & $\begin{array}{c}0.0084 \\
(0.0096) \\
\end{array}$ & $\begin{array}{c}0.88 \\
(0.386) \\
\end{array}$ \\
\hline Toplu Sözleşme & $\begin{array}{l}-0.0436 \\
(0.0124)\end{array}$ & $\begin{array}{c}-3.50 \\
(0.001)^{*}\end{array}$ \\
\hline
\end{tabular}


Tablo 5'de verilen analiz sonuçlarına göre, kişi başına düşen gelir ve haftalık çalışma saatleri arasında istatistiksel olarak anlamlı ve negatif bir ilişki bulunmuştur. Diğer bir ifade ile kişi başına düşen gelir düzeyinde meydana gelecek \%1'lik artışın, haftalık çalışma saatlerini \% 0.1768 düşürdüğü görülmektedir. Dolayısıyla, analiz sonuçları, gelir düzeyinde meydana gelen artışların çalışma saatlerini azalttığını ortaya koymuştur. Çalışmanın teorik kısmında da açıklandığı gibi, bu durum gelir etkisi olarak adlandırılmaktadır.

Analiz sonuçlarına göre, transfer ve sübvansiyonlar ile haftalık çalışma saatleri arasında istatistiksel olarak anlamlı ve negatif bir ilişki bulunmuştur. Buna göre, transfer ve sübvansiyonlar değişkeninde meydana gelecek bir puanlık artış, haftalık çalışma saatlerini \% 0.1164 azaltmaktadır. Dolayısıyla analiz sonuçlarına göre, transfer ve sübvansiyon uygulamalarındaki artışlar haftalık çalışma saatlerini düşürmüştür. Çalışmanın teorik kısmında da açıklandığı üzere, hükümet tarafından yüksek düzeyde transfer ve sübvansiyon uygulanması, bir anlamda bireylerin gelir düzeyinde yaşanacak bir artış olarak yorumlanabilmektedir. $\mathrm{Bu}$ durumda, bireyin gelir düzeyindeki artış karşısında çalışma sürelerinin azalması, çalışmamızda kullandığımız ülke grubu açısından gelir etkisinin varlığını göstermektedir. Transfer harcamaları, bireylerin gelirlerinde bir artış yaratarak, normal mallara olan taleplerinin artmasına yol açar. Ekonomide boş zaman, piyasa değeri olan, pazarda satış nesnesi olan, bireyi tatmin eden zevklerin getirdiği normal bir mal olarak kabul edilmektedir. Buna bağlı olarak, transfer harcamaları, bireylerin daha az çalışmaları sonucunu ortaya çıkarabilmektedir. Diğer taraftan transfer harcamaları arasında gösterilen işsizlik sigortası ödeneği bireylerin emek arzı üzerinde etkili olabilmektedir. Herhangi bir işte çalıştıkları takdirde işsizlik ödeneğinin kesileceğini düşünen bireyler çalışma konusunda isteksiz davranarak boş zaman tercihlerini arttırabilmektedirler.

Analiz sonuçları, marjinal vergi oranı ve haftalık çalışma saatleri arasında da istatistiksel olarak anlamlı ve negatif bir ilişki olduğunu ortaya koymuştur. Marjinal vergi oranına ait endeks değerlerindeki artışlar, marjinal vergi oranının yükselmesi anlamına gelmektedir. Tablo 5’e göre, marjinal vergi oranı değişkeninde meydana gelecek bir puanlık artış, haftalık çalışma saatlerini \%0.0335 azaltmaktadır. Diğer bir ifade ile marjinal vergi oranları arttıkça, artan gelirin daha yüksek kısmı vergi ödemelerine ayrılmakta, gelir düzeyinde nispi bir azalma ortaya çıkmakta ve haftalık çalışma saatleri azalmaktadır.

Emek gelirleri üzerindeki yüksek oranlı vergiler, insanları çalışmak yerine boş zaman tercihine doğru yön değiştirmeye teşvik edebilecektir (Mocan ve Pogorelova, 2015, s.23). Gelir üzerinden alınan vergi oranlarının arttırılıp azaltılması bir anlamda işçilerin gelirlerinin artması veya azalması anlamına gelebilmektedir. Ekonomik birimler tarafından ödenen vergi oranlarındaki artışlar, gelirin daha yüksek kısmının devlete aktarılmasına yol açtığından kullanılabilir gelir düzeyinde azalma yaşanmasına neden olmaktadır. Örneğin ücretler üzerinden alınan vergi oranları arttırılır ise, bu durum gelir düzeyinde bir azalma sonucunu doguracaktır. Çalışmamızda marjinal vergi oranı ve haftalık çalışma saatleri arasında ortaya çıkan negatif ve anlamlı ilişki, analize dahil olan ülkeler açısından gelir etkisinin işlerliğini ortaya koymaktadır. 
Tablo 5'de verilen analiz sonuçlarına göre, işe alma ve işten çıkarma değişkeni anlamsız çlkarken, işe alma ve asgari ücret değişkeni ve haftalık çalışma saatleri arasında istatistiksel olarak anlamlı ve pozitif bir ilişki bulunmuştur. Tablo 5'e göre, işe alma ve asgari ücret değişkenine ait endeks değerinde meydana gelecek bir puanlık artış, haftalık çalışma saatlerini \% 0.0155 arttırmaktadır. İse alma ve asgari ücret değişkenine ait endeks değerlerindeki artışlar, esnek istihdam sözleşmelerinin olduğu emek piyasasının varlığına işaret etmektedir. Diğer bir ifade ile ülkelerin esnek düzenlemelerin olduğu emek piyasalarına sahip olmaları çalışma sürelerinde artışla sonuçlanabilmektedir. Esnek istihdam sözleşmelerinin varlığı, işletmelerin rekabet gücünü arttırırken, çalışanlara ise çalışma sürelerini istedikleri gibi belirleyebilme imkânını tanımaktadır. Bu durum kadınların işgücüne katılım oranlarının artmasina da olanak vermektedir.

Emek piyasasının bir diğer göstergesi olan toplu sözleşme değişkeni ise istatistiksel olarak anlamlı ve negatif sonuç vermiştir. Toplu sözleşme değişkenine ait endeks değerlerindeki artışlar, şirketlerin toplu sözleşmeleri kendilerinin belirleyebildiklerini (bağımsız olduklarını) göstermektedir. Analiz sonuçları, toplu sözleşme değişkenine ait endeks değerindeki bir puanlık artı̧ıı haftalık çalışma saatlerini \% 0.0436 azaltacağını ortaya koymuştur. Analiz sonuçlarının bu şekilde ortaya çıkması, çalı̧manın teorik kısmında belirtildiği gibi, firmaların çeşitli nedenlerle sözleşme ilişkilerini esnek bir şekilde kendi yapılarına uygun olarak kurmak istemeleri, buna karşılık, çalışanların hak taleplerinin dikkate alınmaması nedeniyle çalışma isteğini azaltmaları ile açıklanabilir.

\section{Sonuç}

Fiyat değişikliği karşısında bireylerin gelir/boş zaman tercihlerinin ne yönde etkilendiğini ortaya koyan birbirine zıt iki etki vardır. Boş zamanların fiyatının artması nedeniyle daha az boş vakit geçirmek ve işe daha fazla vakit ayırmak, "ikame etkisi" olarak ifade edilirken; gelir düzeyi arttıkça boş zaman talebinin de artması "gelir etkisi" olarak adlandırılmaktadır. Ekonomik ve kurumsal faktörlerin toplumların çalışma saatleri üzerindeki etkisinin incelendiği çalışmada, kişi başına düşen GSYİH, transfer ve sübvansiyonlar ve marjinal vergi oranı gibi ekonomik değişkenlerin çalı̧̧ma saatleri üzerindeki etkisi, analize dahil olan ülkeler açısından gelir etkisinin işlerliğini ortaya koymaktadır. Diğer bir ifade ile gelir düzeyinin artması çalışma yükümlülüğünün azalmasıyla sonuçlanmıştır.

Konuyla ilgili literatür incelendiğinde, ekonomik gelişmenin bazı toplumlarda çalışma süresini arttırırken bazı toplumlarda ise boş zaman tercihlerini arttırdığı görülmektedir. ABD'de gelir düzeyindeki artış daha fazla çalışmaya neden olurken, Avrupa'da ise çalışma süresinin azalmasına, boş zaman tercihinin artmasına yol açmaktadır. Çalışmada kullanılan ülke grubu incelendiğinde, ülkelerin çoğunluğunun Avrupa Birliği üyesi ülkeler olduğu görülmektedir. Dolayısıyla, analizde kullanılan her üç ekonomik değişken açısından da, analize dahil olan ülkelerde gelir etkisinin varlı̆̆ı, gelir düzeyi arttıkça Avrupa'da çalışma sürelerinin azalması şeklindeki literatürü desteklemektedir. 
Toplumun kurumsal yapısının bir parçası olarak kültür ve dini inançların da, boş zaman tercihlerini etkileyen faktörler arasında olduğu, konuyla ilgili literatürde yer bulmaktadır. Kurumsal faktörlerin çalışma saatleri üzerindeki etkisini ölçmek amacıyla çalışmada kullanılan toplu sözleşme olanaklarının yüksekliği, işe alma ve asgari ücret, işe alma ve işten çıkarma gibi değişkenlerin çalışma saatleri üzerindeki etkisi, emek piyasasına ait düzenlemelerin işgücü arzı ve çalışma isteğini etkileyerek, çalışma sürelerinin artması veya azalmasında rol oynadığını ortaya koymuştur.

\section{Kaynakça}

Alesina, A., Glaeser, E. \& Sacerdote, B. (2006). Work and Leisure in the United States and Europe: Why So Different?. (20), http://www.nber.org/books/gert06-1 . (Erişim Tarihi: 31.12.2018).

Aytaç, Ö. (2005). Kapitalizm ve Boş Zaman. Eskişehir Osmangazi Üniversitesi Sosyal Bilimler Dergisi, 6(1), 1-22.

Aytaç, Ö., (2002). Boş Zaman Üzerine Kuramsal Yaklaşımlar. Fırat Üniversitesi Sosyal Bilimler Dergisi, 12(1), 231-260. http://web.firat.edu.tr/sosyalbil/dergi/arsiv/cilt12/sayi1/231260.pdf., (Erişim Tarihi: 31.12.2018).

Case, K.E., Fair, R.C. \& Oster, S.M. (2012). Principles of Economics (9th Ed.). Ertuğrul Deliktaş, Metin Karadağ ve Mehmet Güçlü (Çev. Ed.) Ankara: Palme.

Conway, K.S. (1997). Labor Supply, Taxes, and Government Spending: A Microeconometric Analysis. The Review of Economics and Statistics, 79(1), 50-67.

Dokko, J.K. (2007). The Effect of Taxation on Lifecycle Labor Supply: Results from a QuasiExperiment.https://www.federalreserve.gov/pubs/feds/2008/200824/200824pap.pdf, (Erişim Tarihi: 03.07.2018).

Fellner, A. (2008). Role of Culture in Economic Development: Case Study of China and Latin America. Theses and Dissertations Paper 236. University of South Florida Scholar Commons @USF, http://scholarcommons.usf.edu/etd/236, (Erişim Tarihi: 31.12.2018).

Gratton, C. \&Taylor, P. (2004). The Economics of Work and Leisure. John T. Haworth \& A.J. Veal (Ed.), Work and Leisure içinde (s. 85-106). Routledge Taylor Francis Group.

Greif, A., (2006). Institutions and the Path to the Modern Economy. USA: Cambridge University Press. 
Hibbins, R., (1996). Global Leisure. Social Alternatives, (15)1. http://eds.b.ebscohost.com/eds/pdfviewer/pdfviewer?vid=1\&sid=8f77d1f6-9cd0-468987f3-9d94c36944fd\%40sessionmgr101. (Erişim Tarihi: 31.12.2018).

Huberman, M. (2004). Working Hours of the World Unite? New International Evidence of Worktime, 1870-1913, The Journal of Economic History, 64(4), 964-1001

Juniu, S. (2000). Downshifting: Regaining the Essence of Leisure. Journal of Leisure Research, 32(1). https://search.proquest.com/docview/ 201180881/fulltextPDF/DFEEB015F9CE4626PQ/1?accountid=16595, (Erişim Tarihi: 31.12.2018).

Kleven, H.J. \& Kreiner, C.T. (2005). Labor Supply Behavior and the Design of Tax and Transfer Policy.http://citeseerx.ist.psu.edu/viewdoc/download?doi=10.1.1.587.299\&rep=rep1\&ty pe=pdf, (Erişim Tarihi: 03.07.2018).

Kotler, P., Jatusripak, S. \& Maesincee, S. (2005). Ulusların Pazarlanmasi-Ulusal Refahı Oluşturmada Stratejik Bir Yaklaşım. (2.Baskı), Ahmet Buğdaycı (Çev.), İstanbul: Türkiye İş Bankası Kültür.

Kozaryn, A. O. (2011). Europeans Work to Live and Americans Live to Work (Who is Happy to Work More: Americans or Europeans?), J Happiness Stud Resarch Paper, (12), 225 243. DOI 10.1007/s10902-010-9188-8

Mackenzie, G.A, Gerson, P.R. \& Orsmond, D.W.H. (1997). The Composition of Fiscal Adjustment and Growth. IMF Occasional Paper, No:149.

Meghir, C. \& Phillips, D. (2008). Labour Supply and Taxes. Institute for Fiscal Studies, University College London and IZA Discussion Paper No. 3405, 1-56.

Michelacci, C. \& Pijioan-Mas, J. (2007). Why Do Americans Work More than Europeans? Differences in Career Prospects. CEPR Policy Insight, (12).

Mocan, N. \& Pogorelova, L. (2015). Why Work More? The Impact of Taxes and Culture of Leisure on Labor Supply in Europe, Discussion Paper No. 9281Forschungsinstitut zur Zukunft der Arbeit Institute for the Study of Labor.

Monostori, J., (2009). Work, Leisure, Time Allocation, Tárkı European Social Report. http://old.tarki.hu/en/research/european_social_report/monostory_eng_2009.pdf, (Erişim Tarihi: 31.12.2018).

Nickell, S. (2004). Employment and Taxes. CEP Discussion Paper No 634. https://www.nuffield.ox.ac.uk/users/nickell/papers/EmploymentAndTaxes.pdf, 03.07.2018. 
Olovsson, C., (2009). Why Do Europeans Work so Little?. Internatıonal Economic Review, 50(1), 39-61. http://www.jstor.org/stable/20486853, (Erişim Tarihi: 31.12.2018).

Presccott (2004), Why do Americans Work so Much More than Europeans?, Federal Reserve Bank of Minneapolis Quarterly Review, 28(1), 2-13.

Rodríguez, S.P. (2016). The Dynamic Effect of Public Expenditure Shocks in the United States. Documentos de Trabajo No.1628, https://www.bde.es/f/webbde/SES/ Secciones/Publicaciones/PublicacionesSeriadas/DocumentosTrabajo/16/Fich/dt1628e.p df, (Erişim Tarihi: 03.07.2018).

Rogerson, R. (2007). Taxation and Market Work: is Scandinavia an Outlier?. NBERworking paper 12890. http://www.nber.org/papers/w12890.pdf , (Erişim Tarihi: 03.07.2018).

Shermana, A. \& Shavit, T. (2013). The Immaterial Sustenance of Work and Leisure: A New Look at the Work-Leisure Model. The Journal of Socio-Economics, 46, 10-16.

Singh, J., (2016). Individual's Choice between Income and Leisure. http://www.economicsdiscussion.net/income/individuals-choice-between-income-andleisure-explained-with-diagram/1196. (Erişim Tarihi: 31.12.2018).

Smelder, N.J. \& Swedberg, R. (2001). The Sociology of Leisure. New Jersey: Princeton University Press.

Veal, A.J., (2016). Leisure, Income Inequality and the Veblen Effect: Cross-National Analysis of Leisure Time and Sport and Cultural Activity. Roudledge Taylor \& Francis, 35 (2), 215-240. http://dx.doi.org/10.1080/02614367.2015.1036104, (Erişim Tarihi: 31.12.2018).

Wheatley, D. Hardill, I. \& Philp, B., (2011). Managing' Reductions in Working Hours: A Study of Work-time and Leisure Preferences in UK Industry. Review of Political Economy, (23)3, 409-420. Doi: 10.1080/09538259.2011.583832

Williamson, S.D. (2002). Macroeconomics. Boston: Pearson

Yerdelen Tatoğlu, F. (2013). Panel Veri Ekonometrisi, İstanbul: Beta.

Yerdelen Tatoğlu, F. (2017). Panel Zaman Serileri Analizi, İstanbul: Beta.

Yerdelen Tatoğlu, F. (2018). İleri Panel Veri Analizi, İstanbul: Beta. 